Jurnal Akuntansi dan Bisnis: Jurnal Program studi Akuntansi, 6 (1) Mei 2020.

ISSN 2443-3071 (Print) ISSN 2503-0337 (Online). DOI: 10.31289/jab.v6i1.2802

JURNAL AKUNTANSI DAN BISNIS

Jurnal Program Studi Akuntansi

Available online http://ojs.uma.ac.id/index.php/jurnalakundanbisnis

\title{
PENGARUH KEAMANAN ASET PEMERINTAH DAERAH TERHADAP PENYALAHGUNAAN PERALATAN KANTOR: STUDI KASUS DI DINAS PEKERJAAN UMUM DAN PENATAAN RUANG KOTA SALATIGA
}

\author{
Seplina Wulandari ${ }^{a *}$, Marwata ${ }^{a}$ \\ a Fakultas Ekonomi dan Bisnis Unversitas Kristen Satya Wacana Salatiga
}

Diterima Agustus 2019, Disetujui November 2019, Dipublikasikan Mei 2020

\begin{abstract}
Abstrak
Penelitian ini bertujuan untuk mendeskripsikan bentuk-bentuk penyalahgunaan aset peralatan kantor, pencegahan penyalahgunaan peralatan kantor, niat penyalahgunaan dan niat melaporkan penyalahgunaan aset peralatan kantor. Dipemerintahan sangat penting untuk melakukan manajemen aset secara memadai, karena aset daerah merupakan sumber daya yang sangat berperan bagi pemerintah daerah. Penelitian ini dilakukan secara deskriptif dengan pendekatan kuantitatif serta menggunakan data primert. Sampel yang digunakan adalah non probability sampling yaitu purposive sampling. Teknik pengumpulan data yaitu dengan metode survey. Hasil penelitian ini menunjukkan bahwa pegawai Dinas Pekerjaan Umum dan Penataan Ruang (DPUPR) Kota Salatiga menganggap bahwa penggunaan peralatan kantor untuk leperluan pribadi pada saat dijam kerja, diluar jam kerja, membawa pulang dan mengembalikan serta tidak mengembalikan diwaktu berikutnya merupakan bentuk penyalahgunaan peralatan kantor.
\end{abstract}

Kata Kunci: Aset, Barang Milik Daerah, Penyalahgunaan Aset.

\begin{abstract}
This research aims to describe the forms, preventions, intention of abuse, and intentions of report in abusing the official tool assets. In government, it is essential to have adequate asset management because a regional asset is the important resource for a regional government. The research is descriptively using with quantitative approach and primary data. The Sample used is non-probability sampling; purposive sampling. Data collection technique is survey. The research result pointed out that employee at Salatiga Public Work and Space Management Office assumed the use of office tools for personal use in working hours and outer of it, bringing them home, returning, and keeping them in the following time were forms of abusing office tools.
\end{abstract}

Keyword: Asset, Regional Asset, And Abuse Of Assets

How To Cite: Seplina Wulandari, Marwata (2020) Pengaruh Keamanan Aset Pemerintah Daerah Terhadap Penyalahgunaan Peralatan Kantor: Studi Kasus Di Dinas Pekerjaan Umum Dan Penataan Ruang Kota Salatiga. Jurnal Akuntansi dan Bisnis: Jurnal Program Studi Akuntansi, 6 (1): 22 - 35

* email: seplinawulandari09@gmail.com

\section{PENDAHULUAN}

Aset daerah merupakan sumber daya penting bagi pemerintah daerah sebagai penopang utama pendapatan asli daerah. Oleh karena itu, penting bagi pemerintah daerah untuk melakukan manajemen aset secara memadai. Dalam manajemen aset. pemerintah daerah harus menggunakan pertimbangan aspek perencanaan kebutuhan dan penganggaran, pemanfaatan atau penggunaan, pengamanan dan pemeliharaan, penilaian, penghapusan, pemindah tanganan, pembinaan, pengawasan dan pengendalian, pemiayaan dan tuntutan ganti rugi agar aset daerah mampu memberikan kontribusi 
optimal agi pemerintah daerahyang bersangkutan sehingga arah pembangunan di bidang pengelolaan aset daerah dapat terintegrasi dan terprogram dengan baik (Aira, 2014).

Pengoptimalan aset daerah dapat dilakukan dengan pengelolaan aset (managemen aset). Manajemen aset daerah adalah melaksanakan pengelolaan aset / Barang Milik Daerah (BMD) berdasarkan prinsip dasar-dasar manajemen aset terhadap aset / BMD dengan mengikut landasan kebijakan yang diatur berdasarkan Undang-undang, Peraturan Pemerintah, Keppres, Kepmen dan Surat Keputusan lainnya yang berhubungan dengan pengaturan / pengeloaan aset daerah (Budisusilo \& Suryantoro, 2005). Aset atau Barang Milik Daerah (BMD) merupakan seluruh kekayaan yang dimiliki daerah baik yang diperoleh atau dibeli atas beban Anggaran Pendapatan Belanja Daerah (APBD) atau dengan perolehan lain yang sah baik bergerak ataupun tidak bergerak beserta bagian-bagiannya atau dengan satuan tertentu yang dapat dinilai, dihitung, diukur atau ditimbang termasuk hewan dan tumbuhan kecuali uang dan surat berharga (Soleh \& Rochmansjah, 2010). Barang yang dapat bergerak contohnya berupa kendaraan seperti mobil dan motor. Untuk barang yang tidak bergerak contohnya yaitu perlengkapan dan peralatan kantor, seperti komputer, printer, mesin fotokopi, meja, kursi dan lain sebagainya. BMD digunakan oleh karyawan untuk membantu dalam pekerjaan dan digunakan untuk menunjang serta mensukseskan aktivitas atau kegiatan yang diadakan oleh pemerintah.Karyawan dapat memanfaatkan BMD sesuai dengan peraturan dan ketentuan yang berlaku, tetapi karyawan pun dapat melakukan kecurangan serta penyalahgunaan terhadap BMD yang disediakan.Ketika (Eaminers, 2008)melakukan penelitian menunjukkan bahwa pihak karyawan dan para manajer yang senior atau yang ekerja cukup lama yang melakukan kecurangan maupun penyalahgunaan.

Permasalahan umum yang sering terjadi pada pemerintah daerah di Indonesia dalam pengelolaan Barang Milik Daerah adalah belum adanya penerapan aturan atau tata cara pengelolaan BMD yang mengakibatkan BMD belum dapat diinvestasikan secara tepat dan sumer daya manusia yang masih sangat terbatas dan kurang ahli atau kurang terlatih serta mental korupsi, kolusi dan nepotisme yang masih sangat sulit dihilangkan yang mengakibatkan barang yang dikelola cenderung tidak optimal dalam penggunaan dan pemanfaatannya (Shabrina, 2014). Dampak dari sisi keamanan atau hukum terhadap barang yang tidak teradministrasi sengan baik, seperti tidak lengkapnya dokumen kepemilikan akan mengakibatkan hilangnya aset dari tangan Pemerintah Daerah, sehingga pemerintah wajib melakukan pengamanan terhadap BMD. Menurut (Peraturan Menteri Dalam Negeri Nomor 17 tentang Pedoman Teknis Pengelolaan Barang Milik Daerah , 2007),pengamanan adalah kegiatan tindakan pengendalian dalam pengurusan barang milik daerah dalam bentuk pengamanan administrasi, pengamanan fisik dan pengamanan hukum.

Menurut (Association of Certified Fraud Examinations, 2000), salah satu asosiasi di USA yang mendarmabaktikan kegiatannya dalam pencegahan dan pemberantasan kecurangan, mengkategorikan kecurangan dalam tiga kelompok yaitu kecurangan laporan keuangan (Financial Statement Fraud), dapat didefinisikan sebagai kecurangan yang dilakukan oleh manajemen dalam bentuk salah saji material laporan keuangan yang merugikan investor dan kreditor. Kecurangan ini dapat bersifat financial atau kecurangan non-financial. Dan penyalahgunaan aset (Asset Misappropriation), dapat dogolongkan ke dalam 'kecurangan kas' dan 'kecurangan atas persediaan dan aset lainnya', serta pengeluaran-pengeluaran biaya secara curang (fraudulent disursement). Serta korupsi (Corruption), dalam konteks pembahasan ini adalah korupsi menurut $A C F E$, bukannya pengertian korupsi menurut UU Pemerantasan TKP di Indonesia. 
Korupsi terbagi ke dalam pertentangan kepentingan (conflict of interest), suap (bribery), pemerian illegal(illegal gratuity) dan pemerasan (economic extortion).

Aset

Aset adalah nilai dari sesuatu yang dimiliki oleh perusahaan atau instansi dimana barang atau benda terseut mempunyai nilai tukar. Aset dapat diartikan dengan modal atau juga dengan kekayaan. Pengertian aset secara umum ialah barang (thing) atau sesuatu barang (anything) yang mempunyai nilai ekonomi (commercial value) atau nilai tukar (exchange value) yang dimiliki oleh badan usaha, instansi atau individu (perorangan) (Siregar, 2004). Aset atau property adalah sumber daya ekonomi yang dikuasau / dimiliki oleh pemerintah sebagai akibat dari peristiwa masa lalu dan dari manfaat ekonomu / sosial di masa depan diharapkan dapat diperoleh, baik oleh pemerintah maupun masyarakat, serta dapat diukur dalam satuan uang, termasuk sumber dayanon keuangan yang diperlukan untuk penyediaan jasa bagi masyarakat umum dan sumber-sumber daya yng dipelihara karena alasan sejarah dan budaya (Peraturan Pemerintah Nomor 24, 2005).

\section{Aset Daerah atau Barang Milik Daerah (BMD)}

Menurut (Hidayat, 2012), BMD adalah semua kekayaan daerah baik dibeli atau diperoleh atas APBD atau perolehan lain yang sah baik bergerak maupun tidak bergerak beserta bagian-bagiannya dengan satuan tertentu yang bisa dinilai, dihitung, diukur atau ditimbang termasuk hewan dan tumbuhan, kecuali uang dan surat berharga. BMD terdiri dari barang milik Pemerintah Daerah yang penggunaannya atau pemakaiannya berada pada SKPD/Instansi/Lembaga Pemerintah Daerha lainnya sesuai peraturan perundangundangan dan barang milik Perusahaan Daerah atau Badan Usaha Milik Daerah (BUMD) lain dengan status barang dipisahkan. BMD yang dipisahkan adalah barang dengan pengelolaan berada di Perusahaan Daerah atau BUMD lain dengan anggaran yang dibebankan pada anggaran Perusahaan Daerah atau BUMD. Menurut (Republik Indonesia, 2005) aset adalah sumber daya ekonomi yang dikuasai atau dimiliki oleh pemerintah sebagai akibat dari peristiwa masa lalu dengan manfaat ekonomi atau sosial yang diharapkan dapat diperoleh dimasa mendatang baik oleh pemerintah maupun masyarakat serta dapat diukur dengan dalam satuan uang termasuk sumer daya nonkeuangan yang diperlukan untuk penyediaan jasa bagi masyarkat dan sumber daya yang dipelihara karena alasan sejarah dan budaya. Pada manfaat ekonomi, aset pada masa mendatang diharapkan dapat memberikan sumangan baik langsung maupun tidak langsung bagi kegiatan operasional pemerintah berupa aliran pendapatan atau penghematan belanja bagi pemerintah.

Pada (Republik Indonesia, 2005) lampiran II menjelaskan tentang aset, seperti aset diklasifikasikan ke dalam aset lancar dan aset tidak lancar. Suatu aset disebut sebagai aset lancar jika diharapkan dapat segera untuk direalisasikan atau dimiliki agar dipakai atau dijual dalam waktu 12 bulan sejak tanggal pelaporan. Aset yang tidak dapat dimasukkan ke dalam kriteria tersebut diklasifikasikan sebagai aset tidak lancar. Aset lancar seperti setara kas dan kas, piutang, investasi jangka pendek dan persediaan. Aset tidak lancar mencakup aset yang ersifat jangka panjang dan aset tidak berwujud yang digunakan baik langsung maupun tidak langsung untuk kegiatan pemerintah atau yang digunakan masyarakat. Aset tidak lancar diklasifikasikan menjadi investasi jangka panjang, aset tetap, dana cadangan dan aset lainnya. Aset tetap meliputi tanah, peralatan dan mesin, gedung dan bangunan, jalan, irigasi dan jaringan aset lainnya dan konstruksi 
dalam pengerjaan. Aset tidak lancar lainnya diklasifikasikan seagai aset lainnya. Termasuk dalam aset lainnya adalah aset tak berwujud dan aset kerja sama (kemitraan).

\section{Pengamanan Aset}

Pengamanan adalah kegiatan tindakan pengendalian dalam pengurusan arang milik daerah dalam bentuk fisik, administrative dan tindakan upaya hukum dalam hal legal audit merupakan suatu lingkup untuk mengidentifikasi dan mencari solusi atas permasalahan legal mengenai prosedur penguasaan atau pengalihan aset seperti status hak penguasaan yang lemah, aset yang dikuasai pihak lain, pemindahan aset yang tidak termonitor dan lain-lain (Aira, 2014). Pengamanan merupakan kegiatan atau tindakan pengendalian dan penerbitan dalam upaya pengurusan Barang Milik Daerah (BMD) secara fisik, administrasi dan tindakan hukum. Pengmanan dititik beratkan pada penertiban atau pengamanan secara fisik dan administrasi, sehingga barang milik daerah tersebut dapat dipergunakan atau dimanfaatkan secara optimal serta terhindar dari penyerobotan pengambil alihan atau klaim dari pihak lain (Shabrina, 2014).

Pengamanan dilakukan terhadap BMD berupa barang inventaris dalam proses pemakaian dan barang persediaan dalam gudang yang diupayakan secara fisik, administrasi dan tindakan hukum (Shabrina, 2014). Pengamanan fisik barang inventaris, terhadap barang bergerak dilakukan dengan cara pemanfaatan sesuai tujuan, penggudangan atau penyimpanan baik tertutup maupun terbuka dan pemasangan tanda kepemilikan. Pengamanan terhadap barang tidak bergerak dilakukan dengan cara pemagaran, pemasangan papan tanda kepemilikan dan penjagaan. Pengamanan fisik barang persediaan dilakukan oleh penyimpanan dan atau pengurus barang dengan cara penempatan pada tempat penyimpanan yang baik sesuai dengan sifat barang tersebut agar BMD terhindar dari kerusakan fisik.

Pengamanan administrasi barang inventaris, terhadap barang bergerak dilakukan dengan cara pencatatan atau inventarisasi, kelengkapan bukti kepemilikan (BPK, faktur pembelian, dll), serta pemasangan label kode lokasi dan kode barang berupa stiker. Pengamanan administrasi terhadap barang tidak bergerak dilakukan dengan cara pencatatan atau inventarisasi, penyelesaian buku kepemilikan (IMB, Berita Acara Serah Terima, Surat Perijinan, Akte Jual Beli dan dokumen pendukung lainnya). Pengamanan administrasi terhadap barang persediaan dilakukan dengan cara pencatatan dan penyimpanan secara tertib. Pengamanan dengan tindakan hukum terhadap barang inventaris yang bermasalah dengan pihak lain, dilakukan dengan cara negoisasi (musyawarah) untuk mencari penyelesaian dan dengan cara penerapan hukum.

\section{Kecurangan (Fraud)}

Kecurangan didefinisikan sebaga tindakan atau penipuan atau kekeliruan yang dibuat oleh seseorang atau badan yang mengetahui bahwa kekeliruan tersebut dapat mengakibatkan beberapa manfaat yang tidak baik kepada individu atau entitas atau pihak lain (Ernst, 2009). Menurut (The Association of Certified Fraud Examiners, 2016), fraud adalah perbuatan-perbuatan yang melawan hukum yang dilakukan dengan sengaja untuk tujuan tertentu(manipulasi atau memberikan laporan keliru terhadap pihak lain) dilakukan orang-orang dari dalam atau luar organisasi untuk mendapatkan keuntungan pribadi ataupun kelompok yang secara langsung atau tidak langsung merugikan pihak lain.

Kecurangan terjadi ketika salah saji dibuat dalam suatu keadaan yang mengetahui bahwa hal itu adalah suatau kepalsuan dan dilakukan dengan maksud untuk melakukan kecurangan (Arens \& Loebbecke, 2003). Kecurangan akuntansi (fraud) mengacu kepada 
kesalahan akuntansi yang dilakukan secara sengaja dengan tujuan menyesatkan pembaca atau pengguna laporan keuangan (Wells, 2007). Menurut Associaytion of Certified Fraud Eaminer (ACFE), kecurangan akuntansi dapat digolonglan menjadi tiga jenis : kecurangan dalam laporan keuangan, penyalahgunaan aktiva dan korupsi.

Menurut ACFE (Association of Certified Fraud Eaminers), kecurangan terbagi dalam tiga jenis berdasarkan perbuatan yaitu penyimpanan atas aset (asset misappropriation) yaitu penyalahgunaan/pencurian aset perusahaan atau pihak lain, pernyataan palsu (fraudulent statement) yaitu tindakan yang dilakukan oleh pejabat atau eksekutif suatu perusahaan atau instansi pemerintah untuk menutupi kondisi keuangan yang sebenarnya dengan melakukan rekayasa keuangan (financial engineering) dalam penyajian laporan keungan untuk memperoleh keuntungan dan korupsi (corruption) yaitu jenis fraud yang paling sulit dideteksi karena menyangkut kerja sama dengan pihak lain dan saling menikmati keuntungan. Fraud jenis ini banyak terjadi di negara-negara berkembang yang penegakan hukumnya lemah dan masih kurang kesadaran akan tata kelola yang baik sehingga faktor intergritasnya masih dipertanyakan. Termasuk didalamnya adalah penyalahgunaan wewenang/konflik kepentingan (conflict of interest), penyuapan (bribery), penerimaan yang tidak sah/illegal (illegal gratuities), dan pemerasan secara ekonomi (economic extortion).

Terdapat dua jenis kecurangan, yaitu kecurangan pencurian aktiva yang sering disebut penggelapan atau kecurangan pegawai dan pelaporan keuangan yang menyesatkan, yang sering disebut sebagai kecurangan auditan (Murwanto, Budiarjo, \& Ramadhana, 2006).Contoh pencurian aktiva adalah seseorang bendaharawam mengambil gaji pegawai yang telah mengundurkan diri dari pegawai negeri sipil.Contoh pelaporan keuangan yang menyesatkan adalah lebih saji yang disengaja dari harga kontrak pengadaan barang atau jasa. Menurut SAS No.99, terdapat dua jenis kesengajaan penyalahsajian yang relevan dengan audit atas laporan keuangan dan pertimbangan auditor atas terjadinya fraud, yaitu fraudulent financial reporting didefinisikan sebagai salah saji yang disengaja atau kelalaian dalam jumlah atau pengungkapan dalam laporan keuangan yang didesian untuk merugikan pengguna laporan keuangan. Dan misappropriation of assets, penyalahgunaan aset dapat dilakukan dalam beberapa cara (termasuk menggelapkan penerimaan, mencuri aset berwujud dan aset tidak berwujud, atau menyebabkan organisasi membayar untuk barang dan jasa yang tidak diterima (Norbarani, Pendeteksian Kecurangan Laporan Keuangan Dengan Analisis Fraud Triangle Yang Diadopsi Dalam Sas No. 99, 2012). Penyalahgunaan aset juga seringkali disetai dengan pencatatan palsu dalam menyembunyikan fakta bahwa aset yang hilang, tidak langsung menyebabkan penyimpangan akuntansi dalam laporan keuangan.

Menurut (Hall \& Singleton, 2007) ada tiga kategori kecurangan, yaitu kecurangan dalam laporan keuangan, korupsi dan penyalahgunaan aset. Kecurangan dalam laporan keuangan, biasa dikaitkan dengan kecurangan oleh pihak manajemen. Untuk dapat digolongkan sebagai kecurangan jenis ini, laporan itu sendiri harus memberikan manfaat keuangan langsung atau tidak langsung bagi pelakunya. Contoh kesalahan penyajian pada saldo akun kas untuk menutupi kecurangan kas tidak termasuk dalam kecurangan ini. Sebaliknya, menyatakan terlalu rendah kewajiban untuk dapat menyajikan gambaran keuangan perusahaanyang baik agar saham naik termasuk dalam kecurangan ini. Walau kecurangan dalam lapran keuangan hanya merupakan 5\% dari seluruh kasus kecurangan yang terungkap dalam penelitian kecurangan oleh $A C F E$, median kerugian akibat kecurangan semacam ini jauh lebih tinggi daripada kerugian yang diakibatkan oleh korupsi dan penyalahgunaan aset. 
Korupsi (corruption), merupakan kejahatan kerah putih yang paling tua. Korupsi meliputi penyuapan, konflik kepentingan, pemberian tanda terimkasih yang tiak sah dan pemerasan secara ekonomi. Korupsi adalah tindakan seorang pejabat atau petugas yang secara tidak sah dan tidak dapat dibenarkan memanfaatkan pekerjannya atau karakternya untuk mendapatkan keuntungan bagi dirinya sendiri atau untuk orang lain, dengan melanggar kewajiban dan hak orang lain. Berdasarkan Associatio Fraud Examiners $(A C F E)$, korupsi merupakan 10\% dari seluruh kasus kecurangan ditempat kerja. Hampir 90\% kerugian akibat korupsi ditimbulkan dari penyuapan.

Penyalahgunaan Aset, biasa dikaitkan dengan kecurangan oleh karyawan. Penyalahgunaan aset meliputi kecurangan kas, kecurangan transaksi dan kecurangan dengan komputer. Kecurangan transaksi (transaction fraud) melibatkan penghapusan, pengubahan atau penambahan transaksi palsu untuk mengarahkan aset ke pelaku kecurangan. Tekni ini dapat digunakan untuk mengirim persediaan ke pelaku kecurangan, sebagai akibat dari adanya transaksi penjualan palsu atau pengeluaran kas untuk membayar kewajiban palsu. Salah satu kecurangan transaksi yang umum dilakukan melibatkan distribusi cek gaji yang tidak benar untuk karyawan yang tidak ada.

\section{Penyalahgunaan Aset}

Penyalahgunaan aset adalah salah satu bentuk kecurangan yang dilakukan dengan cara memiliki secara tidak sah dan penggelapan terhadap aset pemerintah untuk memperkaya diri sendiri dan memakai aset tersebut untuk kepentingan pribadi, yang biasanya dilakukan oleh karyawan yang bekerja didalam instansi tersebut (Tuanakotta, 2007). Penyalahgunaan aset dapat dilakukan dengan beberapa cara seperti : menggelapkan penerimaan, mecuri aset berwujud dan aset tidak berwujud atau menyebabkan organisasi membayar untuk barang/jasa yang tidak diterima. .Penyalahgunaan aset seringkali disertai dengan pencatatan palsu dalam menyembunyikan fakta bahwa aset yang hilang, tidak langsung menyebabkan penyimpangan akuntansi dalam laporan keuangan (Norbarani, Pendeteksian Kecurangan Laporan Keuangan Dengan Analisis Fraud Triangle Yang Diadopsi Dalam Sas No.99, 2012). Menurut (The Association of Certified Fraud Examiners, 2016)melaporkan bahwa dari 2410 kasus yang diinvestigasi yang terjadi di 114 negara, organisasi rata-rata kehilangan 5\% dari pendapatan tahunannya atau senilai US \$6,3 triliyun karena fraud dan penyalahgunaan (abuse). Terdapat dua faktor risiko yang berkaitan dengan penyalahgunaan aset, yaitu kerentanan penyalahgunaan aset dan pengendalian (Hall \& Singleton, 2007). Kerentanan penyalahgunaan aset, kerentanan untuk melakukan penyalahgunaan aset berkaitan dengan sifat dan tingkatan sejauh mana aset terkait dapat dicuri. Aktiva lnacar seperti kas lebih mudah untuk disalahgunakan dari pada aktiva tidak lancar, seperti perlengkapan fisik pabrik.

Pengendalian, faktor risiko ini melibatkan pengendalian yang didesain untuk mencegah atau mendeteksi penyalahgunaan aset. Contoh, suatu sistem manajemen basis data yang tidak cukup membatasi akses ke catatan akuntansi, akan meningkatkan risiko penyalahgunaan aset. Menurut (Hall \& Singleton, 2007) contoh kecurangan umum yang berkaitan dengan pencurian oleh karyawan (penyalahgunaan aset) meliputi hal-hal seperti pembelian pribadi, karyawan fiktif, beban fiktif, pembayaran yang diubah, pemasok yang tidak benar, pencurian kas atau persediaan, dan juga gali luang tutup lubang. 


\section{Teori Fraud Triangle}

Teori fraud triangle merupakan suatu gagasan yang meneliti tentang penyebab terjadinya kecurangan. Pertama kali diciptakan oleh (Cressey, 1953) dinamakan fraud triangle atau segitiga kecurangan. Fraud triangle menjelaskan tiga faktor yang terdapat dalam setiap situasi fraud seperti preassure (tekanan), opportunity (peluang), dan rationalization (rasionalisasi). Tekanan menyebabkan seseorang melakukan kecurangan, dapat berupa seperti gaya hidup,tuntutan ekonomi, dan lain-lain (Cressey, 1953). Tekanan paling sering terjadi dikarenakan adanya tekanan kebutuhan keuangan. Kebutuhan ini dianggap sebagai kebutuhan yang tidak dapat dibagikan kepada orang lain untuk bersama-sama menyelesaikannya sehingga harus diselesaikan secara tersembunyi dan pada akhirnya menyebabkan terjadinya kecurangan. Menurut SAS No.99, terdapat empat jenis kondisi yang umum terjadi pada tekanan yang dapatmengakibatkan kecurangan yaitu financial stability, external pressure, personal financial need, dan financial targets. Financial stability adalah keadaan yang menggambarkan kondisi keuangan perusahaan dalam kondisi stabil. External pressure adalah tekanan yang berlebihan bagi manajemen untuk memenuhi persyaratan atau harapan dari pihak ketiga. Personal financial need adalah kondisi ketika keuangan perusahaan turut dipengaruhi oleh kondisi keuangan para eksekutif perusahaan. Dan financial targets adalah tekanan berlebihan pada manajemen untuk mencapai target keuangan yang dipatok oleh direksi atau manajemen.

Peluang terjadi karena adanya kelemahan pengendalian internal, ketidakefektifan pengawas manajemen atau penyalahgunaan otoritas atau posisi (Cressey, 1953). Peluang dapat terjadi kapan daja sehingga memerlukan pengawasan. Organisasi harus membangun adanya proses, prosedur dan pengendalian yang bermanfaat dan menempatkan karyawan dalam posisi tertentu agar dapat mencegah kecurangan dan dapat mendeteksi kecurangan (Kusumawardhani, 2005). Dalam SAS No.99 disebutkan bahwa peluang pada financial statement fraud dapat terjadi pada tiga kategori kondisi, seperti nature of industry, ineffective monitoring dan organizational structure.

Nature of industry adalah berkaitan dengan munculya risiko bagi perusahaan yang berkecimpung dalam industry yang melibatkan estimasi dan pertimbangan yang signifikan jauh leih besar. Ineffective monitoring adalah keadaan dimana perusahaan tidak memiliki unit pengawas yang efektif memantau kinerja perusahaan. Dan organizational structure adalah strukter organisasi yang kompleks dan tidak stabil. Rasionalisasi menyebabkan pelaku kecurangan mencari pembenaran atas perbuatannya (Cressey, 1953). Rasionalisasi merupakan bagian yang palin sulit diukur. Contoh faktor risiko : jika CEO atau manajer puncak lainnya sangat tidak peduli pada proses pelaporan keuangan, seperti terus mengeluarkan prakiraan yang terlalu optimis, pelaporan keuangan yang curang lebih mungkin terjadi (Kusumawardhani, 2005).

\section{Pencegahan kecurangan}

Pencegahan kecurangan adalah sebuah upaya guna mengurangi sebab-sebab akan terjadinya suatu perbuatan yang curang sehingga lebih mudah daripada mengatasi kecurangan yang telah terjadi (Amrizal, 2004). Kecurangan sering terjadi pada suatu entitas, apabila pengendalian intern tidak ada atau lemah atau dilakukan dengan longgar atau tidak efektif; pegawai dipekerjakan tanpa memikirkan kejujuran dan integritas mereka; pegawai diatur, dieksploitasi dengan tidak baik, disalahgunakan atau ditempatkan dengan tekanan yang besar untuk mencapai sasaran yang mengarah pada tindakan kecurangan; model manajemen sendiri melakukan kecurangan, tidak efektif dan efisien serta tidak taat pada hukum dan peraturan yang berlaku; pegawai yang 
dipercaya memiliki masalah pribadi yang tidak dapat dipecahkan, biasanya masalah keuangan, keluarga, dan gaya hidup yang berlebihan; serta industry dimana perusahaan menjadi bagiannya memiliki sejarah atau tradisi kecurangan (Amrizal, 2004).

\section{Pelaporan Penyalahgunaan (Whisleblowing)}

Pelaporan penyalahgunaan (whistleblowing) adalah suatu pengungkapan oleh karyawan mengenai suatu informasi yang diyakini mengandung pelanggaran hukum dan peraturan yang berkaitan dengan penyalahgunaan prosedur, penyalahgunaan wewenang, dan membahayakan public dan keselamatan tempat kerja (Yulianto R, 2015). Dalam instansi pemerintah, pengguna potensial sistem whistleblowing adalah para Pegawai Negeri Sipil (PNS) yang bertindak sebagai karyawan. Karena, mereka terlibat langsung dalam kegiatan operasional pemerintah. Seorang whistleblowing harus memiliki keberanian dan keyakinan karena tidankan ini penuh dengan resiko.

\section{METODE PENELITIAN}

\section{Jenis dan Sumber Data}

Penelitian ini ialah penelitian secara deskriptif dengan pendekatan kuantitatif. Pendekatan diskriptif digunakan dengan maksud agar dapat menggambarkan dan menjelaskan secara detail dan rinci tentang suatu fenomena yang diteliti. Dalam penelitian ini menggambarkan dan menjelaskan tentang bentuk-bentuk dan pencegahan atau pengendalian yang dapat diimplementasikan terhadap penyalahgunaan peralatan kantor pada Dinas Pekerjaan Umum (DPU) kota Salatiga.

Sumber data dalam penelitian ini adalah dengan menggunakan data primer, yaitu data yang diperoleh secara langsung oleh peneliti dengan melalui kuesioner yang langsung dibagikan kepada karyawan pada Dinas Pekerjaan Umum Salatiga.Dan menggunakan data sekunder, yaitu data yang diperoleh dari sumber yang telah ada dengan diperoleh dari dokumen maupun berkas yang ada pada DPU kota Salatiga.

\section{Populasi dan Sampel}

Populasi yang digunakan pada penelitian ini adalah karyawan yang ekerja pada Dinas Pekerjaan Umum (DPU) kota Salatiga. Sedangkan sampel yang digunakan dalam penelitian ini dengan menggunakan metode non probability sampling yaitu purposive sampling dimana semua anggota populasi memiliki waktu yang sama untuk dipilih sebagai sampel dengan tujuan tertentu.

\section{Metode Pengumpulan Data}

Teknik pengumpulan data yang digunakan yaitu survey, untuk memperoleh data persepsi karyawan dengan melakukan pembagian kuesioner yang berisi tentang penggunaan peralatan kantor apakah termasuk dalam kecurangan atau penyalahgunaan. Sasaran dari kuesioner ini adalah karyawan yang berada di Dinas Pekerjaan Umum kota Salatiga.

\section{Metode Penelitian}

Pengumpulan data dalam penelitian ini yaitu dengan membagikan angket kuesioner secara langsung kepada karyawan DPU kota Salatiga. Peneliti melakukan pembagian kuesioner dengan mendatangi kantor Dinas Pekerjaan Umum untuk mendapatkan data yang berkaitan dengan indicator dan untuk melakukan pengujian statistika serta menganalisa secara rinci. Kuesioner berisi pernyataan-pernyataan 
mengenail persepsi karyawan terhadap kecurangan atau penyalahgunaan peralatan kantor.

\section{Teknik Analisis Data}

Teknik analisis data yang digunakan dalam penelitian ini adalah teknik analisi deskriptif kuantitatif.Untuk menjelaskan atau member gambaran data yang telah dikumpulkan dan menjelaskan dengan menggunakan analisis statistic deskriptif dimana digunakan untuk menganalisis data.

\section{Instrument Penelitian}

Tabel 1. Operasionalisasi Variabel

\begin{tabular}{|c|c|c|}
\hline Variabel & Definisi Operasional Variabel & Indikator \\
\hline $\begin{array}{l}\text { Bentuk-bentuk } \\
\text { Penyalahgunaan Aset }\end{array}$ & $\begin{array}{l}\text { Penyalahgunaan aset adalah salah satu } \\
\text { bentuk kecurangan yang dilakukan } \\
\text { dengan cara memiliki secara tidak sah } \\
\text { dan penggelapan terhadap aset } \\
\text { pemerintah untuk memperkaya diri } \\
\text { sendiri dan memakai aset tersebut } \\
\text { untuk kepentingan pribadi, yang } \\
\text { biasanya dilakukan oleh karyawan yang } \\
\text { bekerja didalam instansi tersebut. } \\
\text { (Tuanakotta, 2007) }\end{array}$ & $\begin{array}{l}\text { Penggunaan untuk keperluan } \\
\text { pribadi pada saat jam kerja } \\
\text { Penggunaan diluar jam kerja untuk } \\
\text { keperluan pribadi } \\
\text { Membawa pulang dan } \\
\text { mengembalikan dihari berikutnya } \\
\text { Membawa pulang dan tidak } \\
\text { mengembalikan dihari berikutnya }\end{array}$ \\
\hline Upaya Pencegahan & $\begin{array}{l}\text { Pencegahan kecurangan adalah sebuah } \\
\text { upaya guna mengurangi sebab-sebab } \\
\text { akan terjadinya suatu perbuatan yang } \\
\text { curang sehingga lebih mudah daripada } \\
\text { mengatasi kecurangan yang telah } \\
\text { terjadi. (Amrizal, 2004) }\end{array}$ & $\begin{array}{l}\text { Diberikan tanda kepemilikan } \\
\text { Harus digunakan sesuai dengan } \\
\text { SOP yang berlaku } \\
\text { Diadakan pencatatan atau } \\
\text { inventarisasi } \\
\text { Pemasangan label kode } \\
\text { Tindakan hukum }\end{array}$ \\
\hline Niat menggunakan & 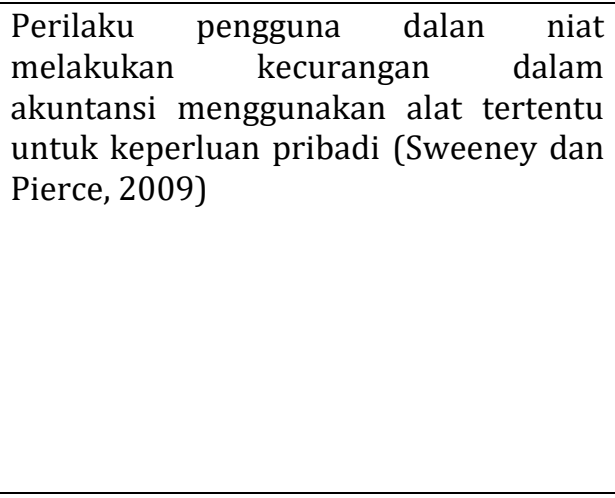 & $\begin{array}{l}\text { Menggunakan peralatan kantor } \\
\text { untuk keperluan pribadi saat jam } \\
\text { kerja } \\
\text { Menggunakan peralatan kantor } \\
\text { untuk keperluan pribadi diluar jam } \\
\text { kerja } \\
\text { Membawa pulang peralatan kantor } \\
\text { dan mengembalikan diwaktu } \\
\text { berikutnya } \\
\text { Membawa pulang peralatan kantor } \\
\text { dan tidak mengembalikan diwaktu } \\
\text { berikutnya }\end{array}$ \\
\hline $\begin{array}{l}\text { Niat untuk } \\
\text { melaporkan } \\
\text { penyalahgunaan }\end{array}$ & $\begin{array}{l}\text { Pelaporan penyalahgunaan } \\
\text { (whistleblowing) adalah suatu } \\
\text { pengungkapan oleh karyawan } \\
\text { mengenai suatu informasi yang diyakini } \\
\text { mengandung pelanggaran hukum dan } \\
\text { peraturan yang berkaitan dengan } \\
\text { penyalahgunaan prosedur, } \\
\text { penyalahgunaan wewenang dan } \\
\text { membahayakan public dan keselamatan } \\
\text { tempat kerja. (Yulianto R, 2015) }\end{array}$ & $\begin{array}{l}\text { Melaporkan langsung kepada } \\
\text { atasan } \\
\text { Menegur kolega } \\
\text { Melaporkan kepada aparat } \\
\text { pengawas } \\
\text { Melaporkan melalui kotak saran } \\
\text { Mengungkapkan melalui media } \\
\text { sosial }\end{array}$ \\
\hline
\end{tabular}




\section{HASIL DAN PEMBAHASAN}

\section{Deskripsi Objek Penelitian}

Objek penelitian dalam penelitian ini adalah PNS yang berada di Dinas Pekerjaan Umum dan Penataan Ruang (DPUPR) kota Salatiga yang beralamat di Jl. A. Yani No. 14. Data penelitian diperoleh dengan cara membagikan kuesioner langsung kepada PNS yang bekerja di DPUPR. Penelitian ini dilakukan dalam waktu 2 ulan yaitu pada bulan februari dan maret 2019. Dalam penelitian ini, peneliti menyebarkan 50 kuesioner yang bisa digunakan sebagai data penelitian. Pembagian kuesioner dapat dilihat pada tabel berikut :

Tabel 2. Rincian Penyebaran Kuesioner

\begin{tabular}{ccc}
\hline Keterangan & Jumlah & Presentase (\%) \\
\hline Total kuesioner yang dibagikan & 50 & $100 \%$ \\
Total kuesioner yang tidak kembali & 19 & $38 \%$ \\
Total kuesioner yang tidak lengkap & - & - \\
Total kuesioner yang bisa digunakan & 31 & $62 \%$ \\
\hline
\end{tabular}

\section{Karakterisitik Umum Responden}

Karakteristik responden dalam penelitian ini terbagi menjadi tiga kategori yaitu karakterisitik responden berdasarkan jenis kelamin, karakteristik berdasarkan pendidikan terakhir dan karakterisitik berdasarkan jabatan. Ketiga karakteristik responden tersebut dapat dijelaskan pada tabel berikut :

Tabel 3. Karakteristik Umum Responden

\begin{tabular}{cccc}
\hline No & Keterangan & Jumlah & Presentase (\%) \\
\hline 1 & Jenis Kelamin & & \\
& Laki-laki & 21 & $70 \%$ \\
& Perempuan & 9 & $30 \%$ \\
Total & 30 & $100 \%$ \\
2 & Tingkat Pendidikan Terakhir & & \\
& SD & - & $0 \%$ \\
& SMP & - & $0 \%$ \\
& SMA/SMK & 5 & $17 \%$ \\
& D3 & 6 & $20 \%$ \\
& S1 & 13 & $23 \%$ \\
& Lain-lain & 6 & $100 \%$ \\
& Total & 30 & $13 \%$ \\
3 & Jabatan & & $87 \%$ \\
& Kepala Bagian & 4 & $100 \%$ \\
\hline
\end{tabular}

\section{Statistik Deskriptif}

Variabel-variabel Keamanan Aset Pemerintah Daerah : Studi atas Penggunaan Peralatan Kantor Dinas Pekerjaan Umum dan Penataan Ruang kota Salatiga berdasarkan kategori dapat dilihat pada tabel berikut :

Tabel 4. Kategori Skor

\begin{tabular}{ccc}
\hline No & Rentang Skor & Kategori Skor \\
\hline 1 & $0,8-1,6$ & Sangat Tidak Setuju \\
2 & $1,7-2,4$ & Tidak Setuju \\
3 & $2,5-3,3$ & Netral \\
4 & $3,4-4,2$ & Setuju \\
5 & $4,3-5$ & Sangat Setuju \\
\hline
\end{tabular}




\section{Bentuk-bentuk penyalahgunaan peralatan kantor}

Berdasarkan analisis data dapat diketahui bahwa variabel bentuk-bentuk penyalahgunaan peralatan kantor pada DPUPR kota Salatiga memperoleh total rata-rata 2,2. Berikut pemaparan untuk masing-masing item dalam variabel bentuk-bentuk penyalahgunaan peralatan kantor pada DPUPR :

Tabel 5. Rata-rata Bentuk Penyalahgunaan Peralatan Kantor

\begin{tabular}{ccc}
\hline No & Bentuk-bentuk Penyalahgunaan & $\begin{array}{c}\text { Rata-rata } \\
\text { Skor }\end{array}$ \\
\hline 1 & Penggunaan peralatan kantor untuk keperluan pribadi pada saat jam & 2,4 \\
kerja & 2,17 \\
2 & Penggunaan peralatan kantor diluar jam kerja untuk keperluan pribadi & 2,5 \\
3 & Membawa pulang peralatan kantor dan mengembalikan peralatan kantor & tersebut diwaktu berikutnya \\
& Membawa pulang peralatan kantor dan tidak mengembalikan peralatan & 1,73 \\
4 & kantor tersebut diwaktu berikutnya & 2,2 \\
\hline
\end{tabular}

Berdasarkan tabel diatas dapat diketahui bahwa dari 30 responden memberikan jawaban dengan rata-rata keseluruhan 2,2 yang berarti responden tidak setuju jika penggunanaan peralatan kantor untuk keperluan pribadi saat jam kerja dan diluar jam kerja, membawa pulang serta dikembalikan maupun tidak dikembalikan dianggap sebagai bentuk penyalahgunaan peralatan kantor. Dari 30 responden memberikan jawaban dengan rata-rata skor 2,4 untuk bentuk penyalahgunaan pertama yang berarti bahwa responden tidak setuju dengan penggunaan peralatan kantor untuk keperluan pribadi pada saat jam kerja. Hal tersebut menjelaskan bahwa PNS menganggap bahwa penggunaan peralatan kantor untuk keperluan pribadi pada saat jam kerja merupakan bentuk penyalahgunaan. Responden tidak setuju bahwa penggunaan peralatan kantor diluar jam kerja untuk keperluan pribadi dengan skor rata-rata 2,17 yang berarti bahwa PNS menganggap penggunaan peralatan kantor diluar jam kerja untuk keperluan pribadi merupakan bentuk penyalahgunaan.

Responden memilih bersikap netral dengan pertanyaan membawa pulang peralatan kantor dan mengembalikan peralatan kantor tersebut diwaktu berikutnya dengan skor rata-rata 2,5. Hal ini membuktikan bahwa PNS netral dengan menganggap membawa pulang peralatan kantor dan mengembalikan peralatan kantor tersebut diwaktu berikutnya merupakan bentuk penyalahgunaan. Responden tidak setuju dengan membawa pulang peralatan kantor dan tidak mengembalikan peralatan kantor tersebut diwaktu berikutnya dengan skor rata-rata 1,73 yang berarti bahwa PNS menganggap membawa pulang peralatan kantor dan tidak mengembalikan peralatan kantor tersebut diwaktu berikutnya merupakan bentuk penyalahgunaan.

\section{Pencegahan penyalahgunaan peralatan kantor}

Berdasarkan analisis data dapat diketahui bahwa variabel pencegahan penyalahgunaan peralatan kantor pada DPUPR kota Salatiga memperoleh total rata-rata 4,21 . Berikut pemaparan untuk masing-masing-masing item dalam variabel pencegahan penyalahgunaan peralatan kantor pada DPUPR : 
Tabel 6. Rata-rata Pencegahan Penyalahgunaan Peralatan Kantor

\begin{tabular}{|c|c|c|}
\hline No & Pencegahan penyalahgunaan peralatan kantor & $\begin{array}{l}\text { Rata-rata } \\
\text { Skor }\end{array}$ \\
\hline 1 & $\begin{array}{c}\text { Di instansi tempat saya bekerja, setiap peralatan kantor yang disediakan } \\
\text { diberikan tanda kepemilikan untuk karyawan yang menggunakan }\end{array}$ & 3,67 \\
\hline 2 & $\begin{array}{c}\text { Di instansi tempat saya bekerja, setiap peralatan kantor yang disediakan } \\
\text { harus digunakan sesuai dengan tujuan dan SOP yang berlaku }\end{array}$ & 4,17 \\
\hline 3 & $\begin{array}{c}\text { Di instansi tempat saya bekerja, diadakan pencatatan atau inventarisasi } \\
\text { terhadap peralatan kantor yang disediakan }\end{array}$ & 4,5 \\
\hline 4 & $\begin{array}{c}\text { Di instansi tempat saya bekerja, diadakan pemasangan label kode } \\
\text { terhadap setiap peralatan kantor yang disediakan }\end{array}$ & 4,53 \\
\hline \multirow[t]{2}{*}{5} & $\begin{array}{l}\text { Di instansi tempat saya bekerja, ada tindakan hukum jika terjadi } \\
\text { pencurian maupun penggelapan terhadap peralatan kantor yang } \\
\text { disediakan }\end{array}$ & 4,17 \\
\hline & Rata-rata & 4,21 \\
\hline
\end{tabular}

Berdasarkan tabel diatas dapat diketahui bahwa 30 responden memberikan jawaban dengan skor rata-rata 3,67 yang berarti bahwa responden setuju dengan setiap peralatan kantor yang disediakan diberikan tanda kepemilikan untuk karyawan yang menggunakan. Responden setuju dengan setiap peralatan kantor yang disediakan harus digunakan sesuai dengan tujuan dan SOP yang berlaku dengan skor rata-rata 4,17. Responden sangat setuju dengan diadakannya pencatatan atau inventarisasi terhadap peralatan kantor yang disediakan dengan skor rata-rata 4,5. Responden sangat setuju dengan diadakan pemasangan label kode terhadap peralatan kantor yang disediakan dengan skor rata-rata 4,53. Responden setuju dengan adanya tindakan hukum jika terjadi pencurian maupun penggelapan terhadap peralatan kantor yang disediakan dengan skor rata-rata 4,17.

\section{Niat penyalahgunaan peralatan kantor}

Berdasarkan analisi data dapat diketahui bahwa variabel niat penyalahgunaan peralatan kantor pada DPUPR kota Salatiga memperoleh total rata-rata 2,0. Berikut pemaparan untuk masing-masing item dalam variabel niat penyalahgunaan peralatan kantor pada DPUPR :

Tabel 7. Niat Penyalahgunaan Peralatan Kantor

\begin{tabular}{lll}
\hline No & Niat penyalahgunaan peralatan kantor & $\begin{array}{l}\text { Rata-rata } \\
\text { Skor }\end{array}$ \\
\hline 1 & $\begin{array}{l}\text { Jika ada kesempatan, saya akan menggunakan peralatan kantor untuk } \\
\text { keperluan pribadi pada saat jam kerja }\end{array}$ & 2,03 \\
2 & $\begin{array}{l}\text { Jika ada kesempatan, saya akan menggunakan peralatan kantor untuk } \\
\text { keperluan pribadi diluar jam kerja }\end{array}$ & 2,00 \\
3 & $\begin{array}{l}\text { Jika ada kesempatan, saya akan membawa pulang peralatan kantor dan } \\
\text { mengembalikan diwaktu berikutnya }\end{array}$ & 2,3 \\
4 & $\begin{array}{l}\text { Jika ada kesempatan, saya akan membawa pulang peralatan kantor dan } \\
\text { tidak mengembalikan diwaktu berikutnya }\end{array}$ & 1,67 \\
Rata-rata & 2,00 \\
\hline
\end{tabular}

Berdasarkan tabel diatas dapat diketahui bahwa 30 responden memberikan jawaban dengan skor rata-rata 2,03 yang berarti bahwa responden tidak setuju dengan pertanyaan jika ada kesempatan peralatan kantor akan digunakan untuk keperluan pribadi pada saat jam kerja. Responden tidak setuju dengan pertanyaan jika ada kesempatan peralatan kantor akan digunakan untuk keperluan pribadi diluar jam kerja dengan memperoleh skor rata-rata 2,00. Responden tidak setuju dengan pertanyaan jika ada kesempatan peralatan kantor akan dibawa pulang dan dikembalikan diwaktu 
berikutnya dengan memperoleh skor rata-rata 2,3. Responden sangat tidak setuju dengan pertanyaan jika ada kesempatan peralatan kantor akan dibawa pulang dan tidak dikembalikan diwaktu berikutnya dengan skor rata-rata 1,67.

\section{Niat melaporkan penyalahgunaan peralatan kantor}

Berdasarkan analisis data dapat diketahui bahwa variabel niat melaporkan penyalahgunaan peralatan kantor pada DPUPR kota Salatiga memperoleh total rata-rata 3,10. Berikut pemaparan untuk masing-masing item dalam variabel niat melaporkan penyalahgunaan peralatan kantor pada DPUPR :

Table 8. Niat Melaporkan Penyalahgunaan Peralatan Kantor

\begin{tabular}{ccc}
\hline No & Niat melaporkan penyalahgunaan peralatan kantor & $\begin{array}{c}\text { Rata-rata } \\
\text { Skor }\end{array}$ \\
\hline 1 & Jika ada kolega yang melakukan penyalahgunaan, saya akan langsung \\
melaporkan kepada atasan & 3,3 \\
2 & Jika ada kolega yang melakukan penyalahgunaan, saya akan menegur \\
kolega & 3,63 \\
3 & Jika ada kolega yang melakukan penyalahgunaan, saya akan melaporkan & 3,13 \\
4 & Jepada aparat pengawas & 3,23 \\
5 & Jika ada kolega yang melakukan penyalahgunaan, saya akan melaporkan & \\
melalui media sosial & Rata-rata & 2,17 \\
\hline
\end{tabular}

Berdasarkan tabel diatas dapat diketahui bahwa 30 responden memberikan jawaban dengan skor rata-rata 3,3 yang berarti responden bersikap netral jika ada kolega yang melakukan penyalahgunaan maka akan langsung dilaporkan kepada atasan. Responden setuju dengan perntayaan jika ada kolega yang melakukan penyalahgunaan maka akan menegur kolega dengan skor rata-rata 3,63. Responden bersikap netral jika ada kolega yang melakukan penyalahgunaan maka akan dilaporkan kepada aparat pengawas dengan skor rata-rata 3,13. Responden akan bersikap netral jika ada kolega yang melakukan penyalahgunaan maka akan dilaporkan melalu kotak saran dengan skor rata-rata 3,23. Responden tidak setuju dengan pertanyaan jika ada kolega yang melakukan penyalahgunaan makan akan diungkapkan melalui media sosial dengan skor rata-rata 2,17.

\section{SIMPULAN}

Penelitian ini memiliki tujuan untuk mendeskripsikan bentuk-bentuk penyalahgunaan aset peralatan kantor, pencegahan penyalahgunaan peralatan kantor, niat penyalahgunaan peralatan kantor dan niat melaporkan penyalahgunaan peralatan kantor.Berdasarkan hasil penelitian pada DPUPR kota Salatiga, maka penelitian ini menyimpulkan bahwa pertama, PNS pada DPUPR kota Salatiga menganggap bahwa penggunaan peralatan kantor untuk keperluan pribadi pada saat jam kerja, diluar jam kerja, membawa pulang peralatan kantor dan mengembalikan diwaktu berikutnya, serta tidak mengembalikan diwaktu berikutnya bukan merupakan bentuk-bentuk penyalahgunaan peralatn kantor. Yang kedua, ada upaya pencegahan penyalahgunaan peralatan kantor yang dilakukan dalam lingkup DPUPR kota Salatiga. Ketiga, tidak ada niat penyalahgunaan peralatan kantor oleh PNS pada DPUPR kota Salatiga. Serta para PNS netral dengan niat melaporkan penyalahgunaan peralatan kantor pada DPUPR kota Salatiga. 
Penelitian ini memiliki keterbatasan hanya dilakukan pada 1 instansi pemerintah daerah sehingga data yang didapatkan juga sedikit yakni dari 50 kuesioner yang dibagikan hanya 30 yang terisi dan dapat diolah. Adapun saran yang diberikan peneliti untuk DPUPR kota Salatiga agar dapat memaksimalkan pembinaan terhadap penggunaan peralatan kantor oleh PNS semata hanya untuk kepentingan kedinasan dalam pelayanan masyarakat. DPUPR kota Salatiga juga diharapkan dapat memaksimalkan pencegahan penyalahgunaan peralatan kantor dan memberi efek jera bagi pelaku penyalahgunaan peralatan kantor agar dapat digunakan secara efektif dan evisien untuk menunjang kepentingan dinas. DPUPR diharapkan dapat memberikan jaminan bagi para pegawai untuk melaporkan tindakan penyalahgunaan peralatan kantor agar tidak ada keragu-raguan untuk melaporkan tindakan penyalahgunaan. Serta saran yang diberikan untuk penelitian selanjutnya yaitu dengan menggunakan metode kualitatif dan tidak hanya menggunakan 1 SKPD.

\section{DAFTAR PUSTAKA}

Aira, A. (2014). Peran Manajemen Aset Dalam Pembangunan Daerah. Jurnal Penelitian Social Keagamaan . Amrizal. (2004). Pencegahan dan Pendeteksian Kecurang oleh Internal Auditor. Diklat BPKP.

Arens, A., \& Loebbecke, J. (2003). Auditing Pendekatan Terpadu. Jakarta: Salemba Empat.

Association of Certified Fraud Examinations. USA. (2000).

Budisusilo, \& Suryantoro. (2005). Penilaian Dan Pengelolaan Aset. Yogyakarta.

Cressey, D. (1953). Other People's Money: a Study in teh Social Psychology of Embezzlement. Glencoe: IL: Free Press.

Eaminers, A. O. (2008). Report to the Nation on Occupational Fraud and Abuse. USA.

Ernst, d. Y. (2009). Detecting Financial Statement Fraud.

Ghozali, I. (2005). Aplikasi Analisis Multivariate dengan SPSS. Semarang: Badan Penerbit UNDIP.

Hall, J. A., \& Singleton, T. (2007). Audit dan Assurance Teknologi Informasi 2 . Jakarta: Salemba Empat.

Hidayat, M. (2012). Manajemen Aset (Privat dan Publik). Yogyakarta: LaksBang PRESSind.

Kusumawardhani, P. (2005). Deteksi Financial Statement Fraud Dengan Analisis Fraud Triangle Pada Perusahaan Perbankan Yang Terdaftar Di BEI.

Murwanto, R., Budiarjo, A., \& Ramadhana, F. H. (2006). Audit Sektor Publik: Suatu Pengantar bagi Pembangunan Akuntabilitas Instansi Pemerintah. Jakarta: LPKP AP.

Norbarani, L. (2012). Pendeteksian Kecurangan Laporan Keuangan Dengan Analisis Fraud Triangle Yang Diadopsi Dalam Sas No. 99.

Norbarani, L. (2012). Pendeteksian Kecurangan Laporan Keuangan Dengan Analisis Fraud Triangle Yang Diadopsi Dalam Sas No.99.

Peraturan Menteri Dalam Negeri Nomor 17 (2007). Tentang Pedoman Teknis Pengelolaan Barang Milik Daerah .

Republik Indonesia. (2005). Peraturan Pemerintah Nomor 24 tentang Standar AkuntansinPemerintah.

Sarjono, H., \& Julianita, W. (2011). SPSS vs LISREL: Sebuah Pengantar, Aplikasi untuk Riset. Jakarta: Salemba Empat.

Shabrina, K. N. (2014). Efektivitas Pengamanan Aset dalam Mewujudkan Akuntabilitas di Pemerintah Kota Surabaya. ISSN 2303 - 341X.

Siregar, D. D. (2004). Manajemen Aset. Jakarta: Satyatama Graha Tara.

Soleh, C., \& Rochmansjah, H. (2010). Pengelolaan Keuangan dan Aset Daerah . Bandung: Fokusmeedia.

Sulistomo, A. (2012). Persepsi Mahasiswa Akuntansi Terhadap Pengungkapan Kecurangan .

The Association of Certified Fraud Examiners. (2016). Report to the Nation on Occupational Fraud and Abuse. USA.

Tuanakotta. (2007). Association of Certified Fraud Examiners (ACFE). Amerika Serikat.

Wells, J. T. (2007). Corporate Fraud Handbook: Prevention and Detection: Second Edition. Jonh Wiley and Sons Inc.

Yulianto R, D. A. (2015). Pengaruh Orientasi Etika, Komitmen Profesional, dan Sensitifitas Etis terhadap Whistleblowing. 